Online: http://journal.uny.ac.id/index.php/jppfa

\title{
HUMANIZATION OF MATHEMATICS LEARNING
}

Sandra Bayu Kurniawan, Noeng Muhadjir

SMA Negeri 1 Dlingo Yogyakarta, Program Pascasarjana Universitas Negeri Yogyakarta sandrabayukurniawan@gmail.com

\begin{abstract}
The study concerned here was to describe (1) the characteristics of humanistic mathematics learning and (2) the stages to actualize such learning. The said study was a qualitative one employing the phenomenological approach with six stages of inductive analysis. The data were validated by using the data source triangulation technique. The study involved 75 students of an elementary school, SD Mangunan, Berbah, Sleman, 36 students of a state senior high school, SMA Negeri 1 of Sewon, Bantul, and 42 students of another state senior high school, SMA Negeri 1 of Dlingo, Bantul. The results of the validation showed that the data were valid and consistent. The conclusions of the study are as follows. (1) Humanistic mathematics learning is characterized by the facts that the use of the mathematics learning media gives students space and time to explore and construct mathematical concept understanding and mathematics learning methods are applied by using an inductive approach. (2) The stages to realize humanistic mathematics learning include the setting of mathematics learning objectives based on humanism, existentialism, and religious teachings by building individual students' strengths through independent and civilized manners, the setting of mathematics learning goals emphasizing balance among the domains of idea, intention, and action, and the setting of the development of contextual and cooperative mathematics learning strategies.
\end{abstract}

Keywords: humanization, mathematics learning 


\section{INTRODUCTION}

School management, in outline, is divisible into three processes, namely, the input process, the learning management process, and the output process. These three processes are interrelated and become one of the measuring instruments in indicating school existence in public. The high percentage of a school's graduates absorbed into favorite higher-level educational institutions would significantly result in a high degree of people's faith in entrusting their sons and daughters to the school's care. The high degree of people's enthusiasm in leaving their children to the school shows a high degree of their trust in its learning management process.

The causal law seeming to be in effect in the case above is inseparable from students' condition at an SD (sekolah dasar 'elementary school'), i.e., SD Mangunan, Sleman, in a KKO (kelas khusus olahraga 'special class of sports') at an SMA Negeri (sekolah menengah atas negeri 'state senior high school', the $2^{\text {nd }}$ level of the two-level system of high school), i.e., SMA Negeri 1 of Sewon, Bantul, and another SMA Negeri, i.e., SMA Negeri 1 of Dlingo, Bantul. The inclusion of several special students left under the school's care while they were originally street children, the presence of students who are pushed aside from the learning for the reason of being given the attribute of stupid students, and the failure in accommodating students who are high achievers in certain fields but low achievers in other fields are illustrations of the condition of students enrolled at SD Mangunan. Attaining low grades ranging between 14 and 22 for four school subjects in the UN (ujian nasional 'national examinations') at SMP (sekolah menengah pertama 'junior high school', the $1^{\text {st }}$ level of the two-level system of high school), possessing psychomotor achievement (i.e., sports skills), not sufficiently responding to lessons much held in the classroom (by, for example, sleeping, chatting, and asking for permission to leave a moment during class), and not having any desire to enter a PT (perguruan tinggi 'higher educational institution' such as university) are illustrations of students in the KKO at SMA Negeri 1, Sewon. Meanwhile, seeking a schooling at minimum or no cost, accepted as students whatever grades are obtained in the
UN at SMP, more enthusiastic in learning activities outside the classroom (like training, exercise, and practice in performing ketoprak, a type of Javanese traditional dramatic play, karawitan, Javanese traditional orchestral music, and dangdut music, Indonesian popular traditional music with Hindustani, Malay, and Arabic elements, and other artistic activities), not showing sufficiently optimum response to learning (by not being sufficiently enthusiastic in going to school, by bringing to class some but not all the needed lesson books needed, by not doing homework, by sleeping in class, and by often asking for permission to leave the class a moment), and not having any idea of entering a PT for further study are illustrations of students at SMA Negeri 1 Dlingo.

Table 1. Grades Attained in the UN at SMP for the School Subject of Mathematics

\begin{tabular}{lll}
\hline \multicolumn{1}{c}{ School } & $\begin{array}{l}\text { UN Grades } \\
\text { of Year 2010 }\end{array}$ & $\begin{array}{l}\text { UN Grades } \\
\text { of Year 2011 }\end{array}$ \\
\hline Special Class & Highest: 6.20 & Highest: 6.75 \\
of Sports, & Lowest: 2.30 & Lowest: 2.20 \\
SMA N 1 of & Mode at & Mode at \\
Sewon & Grade 3.50 & Grade 3.75 \\
SMA N 1 of & Highest: 6.45 & Highest: 6.50 \\
Dlingo & Lowest: 2.10 & Lowest: 2.20 \\
& Mode at & Mode at \\
& Grade 3.25 & Grade 3.25 \\
\hline
\end{tabular}

The low grades for mathematics in the UN at SMP become the focus of public discussions each year. That focus causes pros and cons among people concerning whether to hold that national occasion of the UN. The students and the parents alike become stressed as the time for the UN approaches and the loss of the students' freedom to play is one of the arguments for refusing the holding of the UN. On the other hand, the Indonesian people's culture of needing to be given a challenge and to have an instrument for measuring educational achievement are among the arguments in support of holding the UN. The problem causing the low grades obtained in that $\mathrm{UN}$, according to the review conducted prior to research specifically concerned here, could be formulated as follows: the learning conducted is textual in nature, no time is provided for proving oneself by making use of one's senses, the mathematics learning content 
transferred has the nature of a conclusion already and there is no effort to relate it with the context available in the social environment, the learning is an act of mere memorization in nature, there is no sufficient skill in constructing and utilizing mathematical characteristics or rules, there is weakness in dealing with problems expressed in narrative form, and there is no consistency.

From the seven problem points above, it is inferred that the mathematics learning process has contributed to the appearance in the students of an insufficiently-wise mindset and a low determination to fight for something. That there are no restricting rules for one living in the streets and there one has no hope for a better future has been the opinion of some children before becoming students at SD Mangunan. That opinion has indirectly self-positioned themselves as useless members of society. That attending university-level classes is only for those with high academic achievement, lessons other than those of sports would make the mind become dizzy and mixed-up, and such education requires great expense has been the opinion of the KKO students. Meanwhile, the opinion of students of SMA Negeri 1 of Dlingo has been that making doors and windows already suffices to make one's living, attending university-level classes is highly expensive and only for students with high academic achievement, and after graduating from such classes, it is not a sure thing that one would find work. Such thinking pattern which is not sufficiently wise exerts impacts in the form of social problems among which are students' delinquency and the increase of early marriages among those still of the learning ages. It is proven by the data from KUA (Kantor Urusan Agama 'the Office of Religious Matters') of Kec. (Kecamatan 'the Sub-District of') Dlingo in 2015 as follows Table 2.

The aforementioned condition has changed after the mathematics learning process was conducted by accommodating the potential already possessed by the students. The change occurring at SD Mangunan is that the students who were originally street children have begun to understand the use of politeness in speaking and doing things, to be able to involve themselves in dialogues with fellow students, to gladly give help when their friends need it, to willingly do assignments in mathe-matics, and to attain grades that are above the KKM (kriteria ketuntasan minimal 'minimum mastery criteria'). The change among the students of the KKO at SMA N 1 of Sewon is that it could be said that there is no request for permission to leave the class a moment anymore, they are willing to do mathematical assignments during the learning process, they feel the desire to enter a PT for further study or to have a job, and they respond positively in each semester test (by doing the test well). The change at SMA N 1 of Dlingo is that the views of students, teachers, members of the school administration staff, and the school committee officials have begun to indicate a positive change in thinking pattern concerning the school management. Via an approach in faith (through the teachings of the Islam religion), the use of the sense in the following expressions, namely, "man jaddah wa jaddah", which is Arabic, and "name your child well because you and your child do not live in the same era", as principle for the desire to change; providing the drum band extracurricular activity with a teacher who is a practitioner working as a trainer at the AU (Akademi Udara 'Air Academy'); making communications with PT; and applying humanistic learning are all components of the initial step in the school management in awakening the motivation of all members of the school community.

Table 2. Data of Marriages in Kec. Dlingo in 2015

\begin{tabular}{llc}
\hline \multicolumn{1}{c}{ Criteria } & \multicolumn{1}{c}{ Information } & Frequency \\
\hline Early & Woman less than & \multicolumn{1}{c}{9} \\
Marriage & 16 years of age & (Marriage with \\
& Man less than 19 & Dispensation) \\
& years of age & \\
Education & 1. SD & 117 \\
& 2. SMP & 247 \\
& 3. SMA/SMK* & 226 \\
& 4. Higher & 28 \\
& Educational & \\
& Institution & \\
Profession & 1. Farmer & 27 \\
& 2. Employee & 6 \\
& 3. Military /Police & 2 \\
& 4. Trading & 3 \\
& 5. Others & 580 \\
\hline
\end{tabular}

*SMK = sekolah menengah kejuruan

'vocational high school' 
The humanistic learning at the three schools does not refer to the teacher's cognition involving the students, which means that constructing mathematical knowledge in the students has the nature of merely transferring such knowledge from the teacher, who is the person who has it, to the students. Instead, the humanistic mathematics learning begins to pioneer (1) the avoidance of being oriented to examination scores only, (2) the evasion of the form of mathematics learning with the approach of transfer of knowledge, and (3) the positioning of the teacher as facilitator and students as subjects (as in student-centered learning).

The humanistic mathematics learning process actualizes the message outlined in the section technically called Bab 1 Pasal 1 Ayat 1 of the UU RI (Undang-Undang Republik Indonesia 'Law of the Republic of Indonesia', with $b a b$ as main component, pasal as subcomponent, and ayat as sub-sub-component) Number 23 in 2003 concerning the Sisdiknas (Sistem Pendidikan Nasional 'National Educational System') (Department of National Education, 2003) as follows:

Education is a conscious and planned effort to cause a learning atmosphere and a learning process to occur so that learners actively develop their self-potential in order to possess the religious spiritual strength, self-control, personality, intelligence, noble morals, and skills needed by themselves, by their society, by their nation, and by their country.

In humanistic mathematics learning, the learning implementation pays attention to students' existence. Its focus is on how teachers facilitate their students in order that they could learn mathematics with a sense of freedom and responsibility. One of the foundations of humanistic mathematics learning is the use of the contextual approach. It is an approach that is in line with Piaget's theory of cognitive development (Mulyati, 2005, p. 26), which states that assimilation is a process with such a wide coverage that it could be identified as consisting of three types, namely, reproductive (or functional) assimilation, generalization assimilation, and recognitory assimilation. In relation with it, teachers keep making an inventory of the skills that the students possess and accommodating those skills to build in them the concept of mathematics. Some skills that enter the inventory could be seen in Table 3 .

Table 3. Inventory of Sources of Skills \& Facilities Accommodated in Mathematics Learning

\begin{tabular}{|c|c|c|}
\hline No. & $\begin{array}{c}\text { Source of } \\
\text { Authentic } \\
\text { Issues/Problems }\end{array}$ & Competency \\
\hline 1 & $\begin{array}{l}\text { Making doors, } \\
\text { windows, plaited } \\
\text { baskets, students' } \\
\text { desks for } \\
\text { studying, food } \\
\text { covers }\end{array}$ & $\begin{array}{l}\text { 1. Line Equation, } \\
\text { Substitution and } \\
\text { Elimination } \\
\text { Methods } \\
\text { 2. Linear Program } \\
\text { 3. Trigonometry } \\
\text { 4. Integral } \\
\text { (Determining } \\
\text { Areas and } \\
\text { Volumes) } \\
\text { 5. Differentiation }\end{array}$ \\
\hline 2 & Clothing & $\begin{array}{l}\text { 6. Permutation and } \\
\text { Combination } \\
\text { 7. Geometry } \\
\text { 8. Transformation } \\
\text { 9. Linear Equation } \\
\text { 10. Circle Equation } \\
\text { 11. Linear Program }\end{array}$ \\
\hline 3 & $\begin{array}{l}\text { Makeup and } \\
\text { Extra Sports } \\
\text { (Volleyball, } \\
\text { Futsal, and } \\
\text { Athletics, } \\
\text { Boy/Girl } \\
\text { Scouting) }\end{array}$ & $\begin{array}{l}\text { 12. Combination } \\
\text { 13. Line Equation } \\
\text { 14. Linear Program } \\
\text { 15. Quadratic } \\
\text { Function } \\
\text { 16. Matrix }\end{array}$ \\
\hline 4 & $\begin{array}{l}\text { Parking Lot, } \\
\text { Motorcycle } \\
\text { Brand Name, } \\
\text { Motorcycle } \\
\text { License Number } \\
\text { Plate, Veranda- } \\
\text { Length Seat }\end{array}$ & $\begin{array}{l}\text { 17. Linear Program } \\
\text { 18. Statistics } \\
\text { 19. Limit } \\
\text { 20. Linear Program } \\
\text { 21. Quadratic } \\
\quad \text { Equation } \\
\text { 22. Matrix } \\
\text { 23. Differentiation }\end{array}$ \\
\hline 5 & $\begin{array}{l}\text { Artistic Skills (in } \\
\text { performing } \\
\text { ketoprak, } \\
\text { jatilan*, dangdut, } \\
\text { etc.) }\end{array}$ & $\begin{array}{l}\text { 24. Linear Program } \\
\text { 25. Matrix }\end{array}$ \\
\hline
\end{tabular}

As seen in the table, the issues are expressed as problems in narrative form and the competency column contains the mathematical material to teach and learn. 
The revelation of character values in mathematics learning is based on the understanding that moral values could basically be revealed and developed in students' personal self through competencies and the process of learning activity. According to the developmental theory, the teacher could direct the students to acts of learning to reveal the meanings of mathematical symbols. This is stated by Suriasumantri (2001, p. 190) as follows mathematics is a language symbolizing a sequence of meanings in a statement that we intend to deliver.

One effect of the neglect done to the contexts of mathematical problems in existence in society is that students have trouble with problems expressed as stories and positioned by the teacher as the only centers of the information to be transferred in the mathematics learning. Students worrying about not being able to understand mathematical concepts and problems expressed in narrative form and in the end receiving low marks in tests are more dominant in telling why the mathematics learning all this time has been centered on the teacher. Such is the condition that has caused the realization of the need to accommodate the skills and the authentic problems to build students' mathematical knowledge. That realization is based on the understanding that, basically, students already have the knowledge and learning experience that they have got from the previous level of educational school unit and or from their social environment. Through a spiritual approach, teachers could understand that the potential possessed by students already exists from the time their mothers are pregnant with them and they also have the belief that human beings are humble subjects and mes-sengers of Allah SWT. The spiritual approach (through the teachings of the Islam religion, that is) needs to be exposed because the majority of people in Indonesia embrace Islam as their religion. This is supported by Hanafi \& Madjid (2007, p. 42), who states as follows:

There are three reasons for seeing the relevance of an effort to look into the teachings of Islam as source of reference for the construction of the idea of civil society in Southeast Asia, namely, (1) there are historically indications that Islam has brought the idea of civil society to the West, from which then it has spread to all nations, (2) sociologically and demographically, Islam is the greatest religion in Southeast Asia, with followers scattered in all territories, and (3) it is important for muslims (i.e., followers of Islam) to rediscover the fundamental teachings of their religion and to see possibilities of developing the teachings in the context of modernity.

The exposition above emphasizes that the approaches in mathematics learning could be grouped into two, namely, the teacher-centered group and the student-centered group. As for the difference between these two groups, it could be explained as follows Table 4 .

That description needs to be put under research and the related phenomena need to be revealed according to the experiences undergone by students and how they do things in their mathematics learning.

So the objective of the research concerned here was to describe the characteristics of the humanistic mathematics learning and the stages in actualizing the humanistic mathematics learning according to students' experience. As for the benefits of the research, its practical benefit is that it gives emphasis that the dynamics of an ever-developing society would cause the necessity of the education whose learning could generate students ready for competition in the world of globalization and its theoretical benefit is that it makes the humanistic mathematics learning serve as reference in constructing the ideal mathematics learning.

\section{METHOD}

The research was qualitative in nature and used a phenomenological approach. Its objectivity was build up on the basis of a phenomenological perspective with a humanization paradigm in a study of mathematics learning. The phenomenological perspective with the humanization paradigm gave students as the subjects of the study the opportunity to make interpretations. The results of the students' interpretations were then studied by the researcher to be reinterpreted until they built knowledge concerning the process and meaning of humanization in mathematics learning. It is all emphasized by Moustakas (Creswell, 2007, p. 156), who says: 
Table 4. Teacher-Centered Learning vs. Student-Centered Learning (Adapted from Brophy, 2002, p. x)

\begin{tabular}{|c|c|c|}
\hline No & Teacher-Centered Learning & Student-Centered Learning \\
\hline 1 & $\begin{array}{l}\text { Knowledge is something already } \\
\text { existing as information transferred } \\
\text { from the teacher or text to students }\end{array}$ & $\begin{array}{l}\text { Knowledge is seen as the result of the individual's } \\
\text { interpretation which keeps developing through } \\
\text { discussions as well as the individual's own discovery }\end{array}$ \\
\hline 2 & $\begin{array}{l}\text { The teacher and text are learning } \\
\text { resources playing very vital parts }\end{array}$ & $\begin{array}{l}\text { Children have the authority to form their own knowledge } \\
\text { according to the experience that they have }\end{array}$ \\
\hline 3 & $\begin{array}{l}\text { The teacher is responsible for the } \\
\text { management of the learning by giving } \\
\text { information and leading students to } \\
\text { learn through activities and tasks }\end{array}$ & $\begin{array}{l}\text { The teacher and students share the responsibility in } \\
\text { initiating and going through the process of learning }\end{array}$ \\
\hline 4 & $\begin{array}{l}\text { The teacher gives explanations, checks } \\
\text { students' understanding, and evaluates } \\
\text { their responses }\end{array}$ & $\begin{array}{l}\text { The teacher acts as leader of discussion who asks } \\
\text { questions, makes clarifications, intensifying dialogues, } \\
\text { and helping groups recognize agreements made within } \\
\text { social groups }\end{array}$ \\
\hline 5 & $\begin{array}{l}\text { Students memorize or replicate the } \\
\text { material that has been explained or } \\
\text { modeled }\end{array}$ & $\begin{array}{l}\text { Students try to have an impression of a new input by } \\
\text { relating the material with their previous knowledge or } \\
\text { collaborating with others in dialogues to construct } \\
\text { comprehension }\end{array}$ \\
\hline 6 & $\begin{array}{l}\text { The discourse on learning emphasizes } \\
\text { drills and recitations for questions that } \\
\text { are convergent (spread out/not } \\
\text { focused) and also emphasizes sure } \\
\text { answers }\end{array}$ & $\begin{array}{l}\text { The discourse on learning emphasizes the process of } \\
\text { discussion of the reflections on the experiences } \\
\text { undergone by students and also emphasizes development } \\
\text { in students' thinking }\end{array}$ \\
\hline 7. & $\begin{array}{l}\text { The learning activity emphasizes } \\
\text { model replication or applications } \\
\text { which require directions given by } \\
\text { stages }\end{array}$ & $\begin{array}{l}\text { The learning activity emphasizes the application of } \\
\text { authentic problems and issues which requires higher- } \\
\text { order thinking }\end{array}$ \\
\hline 8 & $\begin{array}{l}\text { Students tend to work by themselves in } \\
\text { practicing what has been transferred to } \\
\text { them to prepare themselves for } \\
\text { competitions in real life }\end{array}$ & $\begin{array}{l}\text { Students collaborate in a learning community } \\
\text { constructing comprehension through dialogues or based } \\
\text { on their own understanding }\end{array}$ \\
\hline
\end{tabular}

First describe personal experiences with the phenomenon under study. The researcher begins with a full description of his or her own experience of the phenomenon. This is an attempt to set aside the researcher's personal experiences (which cannot be done entirely) so that the focus can be directed to the participants in the study.

The psychological phenomenological approach focuses on research interpretation and on the description of students' experiences.
The first setting of the research was SD Mangunan, Solo Road, Kalitirto, Berbah, Sleman, Yogyakarta. The second one was SMA Negeri 1 of Sewon, Bantul, $5 \mathrm{~km}$ from the province capital, and on Parangtritis Road, Sewon, Bantul, Yogyakarta, while the third one was SMA Negeri 1 of Dlingo in Koripan, Bantul. The part of the research for the level of elementary school was at the SD. It was first conducted from September 2010 to April 2011. Then it was conducted for the second time from August 2011 to April 2012. The part for the level of high school was first conducted from August 2013 to May 2014 at SMA Negeri 1 of Sewon. Then it was con- 
ducted again in the same place from July 2014 to September 2014. Then, from February 2014 to April 2016, it was conducted at SMA N 1 of Dlingo.

The research involved 75 students of SD Mangunan, Berbah, Sleman, 36 students of SMA Negeri 1 of Sewon, Bantul, and 42 students of SMA Negeri 1 of Dlingo, Bantul.

The research action consisted of the steps taken by the researcher. The researcher adopted the stages mentioned by Creswell. They are here presented in Table 5.

Table 5. Data Analysis and Representation by Research Approaches

(Creswell, 2007, pp. 156-157)

\begin{tabular}{|c|c|}
\hline $\begin{array}{l}\text { Data Analysis } \\
\text { and Represen- } \\
\text { tation }\end{array}$ & Phenomenology \\
\hline $\begin{array}{l}\text { Data } \\
\text { managing }\end{array}$ & Create and organize files for data \\
\hline $\begin{array}{l}\text { Reading } \\
\text { memoing }\end{array}$ & $\begin{array}{l}\text { Read through text, make margin } \\
\text { notes, form initial codes }\end{array}$ \\
\hline \multirow[t]{2}{*}{ Describing } & $\begin{array}{l}\text { Describe personal experiences } \\
\text { through epoche }\end{array}$ \\
\hline & $\begin{array}{l}\text { Describe the essence of the } \\
\text { phenomenon }\end{array}$ \\
\hline \multirow[t]{2}{*}{ Classifying } & Develop significant statements \\
\hline & $\begin{array}{l}\text { Group statements into meaning } \\
\text { units }\end{array}$ \\
\hline \multirow[t]{3}{*}{ Interpreting } & $\begin{array}{l}\text { Develop a textural description, } \\
\text { "What happened" }\end{array}$ \\
\hline & $\begin{array}{l}\text { Develop a structural description, } \\
\text { "How" the phenomenon was } \\
\text { experienced }\end{array}$ \\
\hline & Develop the "essence" \\
\hline $\begin{array}{l}\text { Representing, } \\
\text { visualizing }\end{array}$ & $\begin{array}{l}\text { Present narration of the "essence" } \\
\text { of the experience; in tables, } \\
\text { figures, or discussion }\end{array}$ \\
\hline
\end{tabular}

Informants were decided by using a purposive procedure. An informant here was defined as an inside person in the research setting. Moleong (2002, p. 90) says that an informant is a person made use of to provide information concerning the situational and conditional setting of the research. It is in line with the requirements for informants according to Spradley (Muslich, 2007, p. 68), who states that the minimum requirements for choosing a good informant are (1) full encul- turation, (2) direct involvement, (3) unknown cultural atmosphere, (4) sufficient time, and (5) non-analytical nature. In the research, the infor-mants were students.

The qualitative data gathered by the researcher became a source of description. As for the form that qualitative data takes, it is explained by Lofland and Lofland (Moleong, 2002 , p. 112), who state that the main data sources in qualitative research are words and actions while documents and others are additional data sources. To indicate some direction in interviews, the interviewer begins with abstract and general questions and, as the interview goes along, the questions would become increasingly more concrete and detailed. Ibrahim (2009, p. 378) states:

Content analysis does not explicitly present questions. However, if the research program continues, the formulation of concrete questions is very important. In content analysis, questions serve as preconditions for the development of a category scheme. The research questions begin with abstract and general ones and would become increasingly more concrete and detailed according to the material under research.

The data gathered were to be inductively analyzed. The data coming in were first subjected to validation by means of triangulation by the researcher to insure their degree of validity. Paton (Bungin, 2011, p. 265) states:

The triangulation of data sources is done by comparing and checking the degree of reliability of certain information obtained at different times and in different ways. In qualitative research, it is done by (1) comparing the data resulting from the observation with those resulting from the interview, (2) comparing what people say in public with what they say in private, (3) comparing what people say about the research situation with what is said all the time, (4) comparing someone's state and perspective with various opinions and views of others, and (5) comparing interview results with the contents of a related document. The result hoped for of such 
comparisons is some sort of sameness or reasons for the occurrence of difference.

Accordingly, the validation of data obtained in the field would be adjusted to field conditions. Therefore, in order to confirm that the data received had a high degree of reliability, the researcher conducted data validation with the application of the triangulation technique on data sources.

\section{RESULTS AND DISCUSSION}

The research results could be grouped into three as follows. (1) Students' experience when understanding that humanistic mathematics learning accommodates skills and authentic problems builds in them the condition of being ready to comprehend, adapt to, and interact with issues in their environment. It could be noted that there is an admission about their already having learning experience and about the learning stages already being democratic. (2) Students' experience when understanding the revelation of character values in mathematics could be acquired through the content and process of learning activity. It is clarified through the ways in which mathematics learning gives a positive implication (namely, the disappearance of discrimination), it becomes a means of developing self-actualization, it develops character values through school mathematics activities, and the development of character values is obtained via describing the meanings of mathematics content by relating it with religious teachings. (3) Students' experience when going through the process of humanistic mathematics learning positions them as free human individuals. It is clarified through the ways in which the utilization of issues which are simple (in the sense of being authentic), which is a form of school mathematics learning (with mathematics whose approach is inductive), positions students as subjects of mathematics learning and builds their learning the truth about them-selves or their proving themselves by utilizing the senses.

In the following, these research results are discussed. The characteristics of the humanistic mathematics learning are as follows. The construction of the RPP (rencana pelaksanaan pembelajaran 'learning execution plan or, simply, lesson plan') is adapted to students' competence, the construction of the LKS (lembar kerja siswa 'students' worksheet') leads students to being creative and innovative in building mathematical concepts, the utilization of the mathematics learning media gives students time and space to explore and build comprehension of mathematical concepts, mathematics learning methods are used with approaches which have an inductive nature, the methods used are oriented to activity mathematics (or school mathematics), the mathematics learning process is conducted with the cooperative approach, students' reflections inform of having positive learning experience, undergoing stages of achieving mathematical competence that are in line with the development of their logic, and there being the conclusion of each student's activity that the student is ready for the issues in his or her environment.

As for the stages of actualizing the humanistic mathematics learning, the first one is that of deciding the learning objectives of mathematics based on the views of humanism, existentialism, and religious teaching. As for the criteria for the learning process to be called humanistic, they are that (1) it is student-centered and (2) it is actively accomplished by students. The second stage is that of deciding the targets of the mathematics learning balancing the developments of the three domains of cipta ('idea', 'inspiration', etc.), karsa ('intention', 'purpose', etc.), and karya ('action', 'work', etc.), the third stage is that of deciding the development of the strategy of mathematics learning which is contextual and cooperative in nature, the fourth stage is that of developing mathematics learning materials which are meaningful, and the fifth stage is that of deciding a measurable evaluation.

The stages of actualizing the humanistic school mathematics learning could be designed with components as follows: (1) identifying the purpose of mathematics learning humanization, (2) analyzing the form of mathematics learning at school, (3) identifying the outcomes of mathematics learning at school, (4) formulating the targets of school mathematics learning humanization, (5) developing the criteria for the evaluation of mathematics learning at school, (6) revising the mathematics learning at school, (7) developing the strategy of mathematics learning at Volume 5, No 1, June 2017 
school, (8) developing the mathematics learning materials at school, and (9) developing the formative evaluation of the humanistic school mathematics learning, the formative evaluation to be done in two ways, namely, to students as individuals and to students in small groups, and (10) developing the summative evaluation of the humanistic school mathematics learning.

From the above description, the researcher could form the following school mathematics learning humanization system design as follows:



Figure 1. Mathematics Learning Humanization Design

\section{CONCLUSION}

\section{Conclusion}

Scientific development goes along with the development of society's socio-cultural civilization. It would surely build conceptual knowledge of mathematics learning humanization that adjusts to the basis of its society's views.

\section{Suggestion}

The mathematical content needs to be formulated and related to the students' level of maturity, their empirical experience, and the learning resources of the environment known to them. The mathematics learning is conducted through learning stages (from concrete to semi-abstract to abstract) with space and time for students to optimize their senses through the application of school mathematics. Thus, mathematics learning would lead them from the stages of dependence toward those of independence and those of building interdependence.

\section{REFERNCES}

Brophy, J. (2002). Social constructivist teaching: affordances and constraints. Michigan: JAI.

Bungin, B. (2011). Penelitian kualitatif. Yogyakarta: Pustaka Pelajar.

Creswell, J. W. (2007). Qualitative inquiry \& research design: choosing among five approaches. Lincoln: University of Nebraska.

Department of National Education. UndangUndang Nomor 20 Tahun 2003 tentang Sistem Pendidikan Nasional (2003).

Hanafi, H., \& Madjid, N. (2007). Islam dan humanisme, aktualisasi humanisme Islam di tengah krisis humanisme universal. Yogakarta: Pustaka Pelajar.

Ibrahim, A. S. (2009). Metode analisis teks dan wacana. Yogyakarta: Pustaka Pelajar.

Moleong, L. J. (2002). Metodologi penelitian kualitatif. Bandung: PT. Remaja Rosdakarya.

Mulyati. (2005). Psikologi belajar. Yogyakarta: CV. Andi Offset.

Muslich, M. (2007). KTSP: pembelajaran berbasis kompetensi dan kontekstual. Jakarta: PT. Bumi Aksara.

Suriasumantri, J. S. (2001). Filsafat Ilmu: sebuah pengantar populer. Jakarta: Pustaka Sinar Harapan. 